\title{
A família Myrtaceae nas restingas da llha do Maranhão, Brasil
}

\author{
Gabriela dos Santos Amorim ${ }^{1, *}$ (i) e Eduardo Bezerra de Almeida Jr.2 (i) \\ 'Universidade Federal de Pernambuco, Av. Prof. Moraes Rego, 1235, Cidade Universitária, 50670-901, Recife, PE, Brasil. \\ *Autor para correspondência: gabriela_amorim@outlook.com.br \\ 2Universidade Federal do Maranhão, Centro de Ciências da Saúde, Departamento de Biologia, Av. dos Portugueses,
} s/n Bacanga, 65085580 - São Luís, MA, Brasil.

Recebido em 22.IX.2019

Aceito em 27.XI.2020

DOI 10.21826/2446-82312021v76e2021008

RESUMO - Apresentamos o estudo taxonômico das espécies de Myrtaceae do litoral da Ilha do Maranhão. A Ilha está situada no extremo norte do Estado, no centro do "Golfão Maranhense" e contempla quatro municípios: São José de Ribamar, São Luís, Paço do Lumiar e Raposa. O estudo foi realizado com base na análise dos espécimes coletados entre 2016 e 2018 em oito áreas de dunas (Dunas da praia de Araçagi, Guia, Caolho e São Marcos) e restingas (Restinga da praia de Caúra, Ilha de Curupu, Panaquatira e Sítio Aguahy), além de análise do material depositado no acervo do Herbário do Maranhão (MAR). Foram registradas 16 espécies compreendendo seis gêneros. O estudo inclui chaves de identificação das espécies, descrições, ilustrações, comentários sobre semelhanças morfológicas, dados de distribuição fitogeográfica e informações sobre a fenologia reprodutiva.

Palavras-chave: Amazônia Oriental, Flora do Maranhão, Tribo Myrteae, Nordeste

ABSTRACT - The Myrtaceae family in the restingas of the Island of Maranhão, Brazil. We present the taxonomic study for the Myrtaceae species of the litoral of Island of Maranhão. The Island is located in the extreme north of the state, in the center of the "Golfão Maranhense" and includes four municipalities: São José de Ribamar, São Luís, Paço do Lumiar and Raposa. The study was based on the specimens collected in the field between 2016 and 2018 in eight dunes areas (dunes of Araçagi beach, Caolho beach, Guia beach and São Marcos beach) and restinga (Restinga of Caúra beach, Curupu Island, Panaquatira beach and Sítio Aguahy) and analyzes of the material deposited in the collection of the Herbarium of Maranhão (MAR). A total of 16 species and 6 genera. The study includes species identification key, descriptions, illustrations, comments on morphological similarities, phytogeographic distribution data and information on reproductive phenology.

Keywords: Eastern Amazonia, Flora of Maranhão, Tribe Myrteae, Northeast

\section{INTRODUÇÃO}

Myrtaceae (Myrtales) tem distribuição pantropical (Wilson et al. 2001, Judd et al. 2009), com centros de diversidade na Austrália, sudeste da Ásia, sul da América tropical e poucos representantes na África (Wilson et al. 2001), circunscrita a 145 gêneros e aproximadamente 6.000 espécies (Lucas et al. 2019). Segundo a classificação mais recente proposta por Wilson et al. (2005), para Myrtaceae são reconhecidas duas subfamílias, Psiloxyloideae e Myrtoideae, com um total de 17 tribos. Apenas duas tribos ocorrem na América Tropical, ambas pertencentes à subfamília Myrtoideae (Lucas \& Bünger 2015): a tribo Metrosidereae Benth., que contempla o gênero monotípico Tepualia Griseb., restrito ao Chile, e a tribo Myrteae DC. que inclui todas as outras Myrtaceae neotropicais (Wilson et al. 2001, Wilson et al. 2005, Lucas et al. 2007, Cruz et al. 2013).

As espécies de Myrtaceae no Brasil podem ser reconhecidas por suas folhas simples, de margem inteira, opostas, com pontuações translúcidas presentes, flores geralmente brancas, de simetria radial, cálice com a exposição da corola no botão floral ou não, estames livres e numerosos, ovário ínfero ou semi-ínfero e frutos carnosos com uma a numerosas sementes (Landrum \& Kawasaki 1997, Wilson et al. 2001, Rosário et al. 2017). Myrtaceae se destaca no Brasil como uma das famílias de angiospermas mais rica e a terceira com maior taxa de endemismo (Forzza et al. 2012). Está representada por 29 gêneros e aproximadamente 1.193 espécies, das quais 784 são endêmicas, e é amplamente distribuída em todos os biomas brasileiros com maior representatividade na Floresta Atlântica, seguida da Amazônia, Cerrado e Caatinga (The Brazil Flora Group - BFG 2015).

Na Amazônia brasileira 266 espécies circunscritas a 13 gêneros tem ocorrência confirmada (BFG 2015) e as principais contribuições sobre essas espécies amazônicas compreendem os levantamentos florísticos e tratamentos taxonômicos desenvolvidos por Souza et al. (1999), Rosário et al. (2004), Rosário et al (2005), Rosário \& Secco (2006), Rosário et al. (2014a), Rosário et al. (2014b), Rosário \& Secco (2013), Souza et al. (2015), Rosário et al. (2017) e Trindade et al. (2018). Esses estudos reportam novas 
ocorrências, atualizações taxonômicas, comentários sobre características diagnósticas e dados de distribuição geográfica. Enquanto outros estudos sobre a família Myrtaceae na Amazônia brasileira são direcionados apenas para as espécies que apresentam grande importância ecológica e alto potencial econômico (Absy et al. 1980, Falcão et al. 1988, Paraluppi et al. 2002, Suguino et al. 2003, Teixeira et al. 2004, Silva et al. 2015).

Apesar de listada como uma das famílias mais representativas em estudos florísticos e fitossociológicos do estrato arbóreo no litoral brasileiro (Assumpção \& Nascimento 2000, Matias \& Nunes 2001, Galvão et al. 2002, Assis et al. 2004, Scherer et al. 2005, Viana et al. 2006, Guedes et al. 2006, Sacramento et al. 2007, Amaral et al. 2008, Martins et al. 2008, Almeida Jr. et al. 2011, Queiroz et al. 2012, Oliveira et al. 2014, Almeida Jr. et al. 2017) ainda são poucos os estudos taxonômicos direcionados à família Myrtaceae no litoral amazônico. Nesse contexto, o presente estudo teve como objetivo realizar o levantamento da flora da família Myrtaceae em um trecho de litoral amazônico, na Ilha do Maranhão, visando contribuir para o conhecimento das espécies amazônicas, apresentando chave de identificação, descrições, comentários e ilustrações.

\section{MATERIAL E MÉTODOS}

A Ilha do Maranhão, localizada no extremo norte do Estado, ocupa o centro do "Golfão Maranhense", região que separa as Baías de São Marcos e São José de Ribamar (Muniz et al. 1994). A Ilha contempla quatro municípios: São José de Ribamar, São Luís, Paço do Lumiar e Raposa (Fig. 1) e estende-se por aproximadamente $904,5 \mathrm{Km}^{2}$ (Pinheiro 2017). A vegetação tem influência amazônica, com fragmentos de floresta secundária no centro-oeste, manguezais ao sul, e praias arenosas ao norte cobrindo até $8 \mathrm{~km}$ de extensão de vegetação litorânea, dunas, falésias, além de pequenos cursos de água doce (Cabral-Freire \& Monteiro 1993, Muniz et al. 1994, Araújo et al. 2016, Serra et al. 2016).

No litoral da Ilha desenvolve-se uma vegetação herbácea e arbustivo-arbórea. A vegetação arbustivo-arbórea pode ser encontrada sobre as dunas (Cabral-Freire \& Monteiro 1993, Silva et al. 2016) ou próxima à vegetação de transição, situada em meio a fragmentos de floresta Amazônica em regeneração (Serra et al. 2016). Em algumas áreas é possível observar indícios de antropização, como o tráfego intenso e constante de pessoas, incidência de fogo e corte indiscriminado da vegetação (Amorim et al. 2016, Silva et al. 2016).

Os espécimes foram coletados em oito áreas do litoral contemplando quatro municípios: em São José de Ribamar foram amostradas as restingas da praia de Caúra

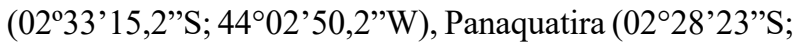

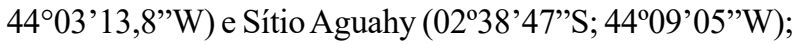
em São Luís, as dunas da praia de Caolho (02 $31^{\prime} 15,1^{\prime \prime}$ 'S;

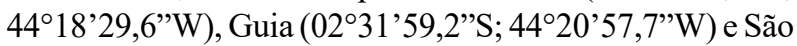
Marcos (02 $29^{\prime} 7^{\prime \prime} S$; $\left.44^{\circ} 15^{\prime} 59^{\prime \prime} \mathrm{W}\right)$; em Paço do Lumiar, as dunas da praia do Araçagi ( $2^{\circ} 27^{\prime} 56^{\prime}$ 'S; $44^{\circ} 10^{\prime} 55^{\prime \prime} \mathrm{W}$ ); e em Raposa, a restinga da Ilha de Curupu (0224'09'S; $44^{\circ} 01^{\prime} 19^{\prime}$ W), (Fig. 1). O clima da Ilha do Maranhão é do

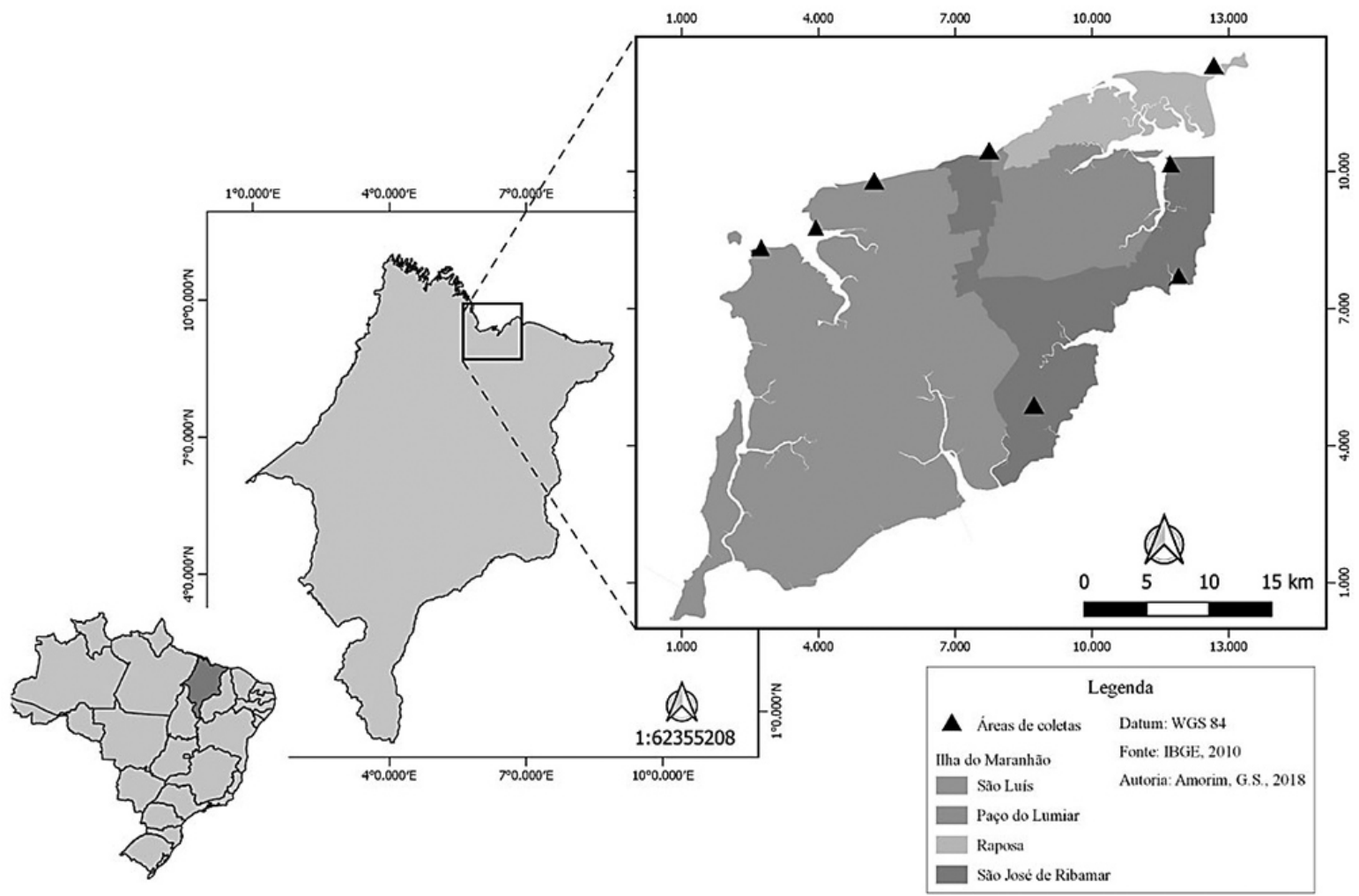

Figura 1. Mapa com a localização das áreas de estudo e municípios da Ilha do Maranhão, Brasil. 
tipo Aw, com duas estações; uma chuvosa que se estende de janeiro a junho e outra seca que segue de julho a dezembro (Alvares et al. 2013), com temperatura média variando de $26^{\circ} \mathrm{C}$ a $27^{\circ} \mathrm{C}$ e pluviosidade de $35 \mathrm{~mm}$ a $2.000 \mathrm{~mm}$ (Instituto Nacional de Meteorologia - INMET 2018).

A análise morfológica teve como base os espécimes coletados entre 2016 e 2018, complementadas com análise do material depositado no acervo do Herbário do Maranhão - MAR (acrônimos conforme Thiers 2018, continuamente editado). O material botânico foi coletado por meio de caminhadas exploratórias e as informações dos espécimes foram anotadas em caderneta de campo, tais como: hábito, altura, coloração das sépalas, pétalas, estames e frutos. $\mathrm{O}$ processo de herborização seguiu a metodologia de Peixoto \& Maia (2013).

Os espécimes foram identificados no Laboratório de Estudos Botânicos (LEB), da Universidade Federal do Maranhão (UFMA), com auxílio de literatura específica (Landrum \& Kawasaki 1997, Souza et al. 1999, Arantes \& Monteiro 2002, Morais \& Lombardi 2006, Bünger et al. 2012, Lourenço \& Barbosa 2012, Giaretta \& Peixoto 2015, Stadnik et al. 2016, Mazine et al. 2016, Trindade et al. 2018), comparação com material do Herbário MAR e de coleções disponíveis online e confirmação de especialista. Para as diagnoses foram usadas as terminologias propostas por Harris e Harris (1994), Landrum e Kawasaki (1997), Souza e Lorenzi (2005) e Mazine et al. (2016). Todo material identificado foi incorporado ao acervo do Herbário MAR.

$\mathrm{O}$ tratamento taxonômico apresentado inclui chave de identificação para as espécies de Myrtaceae ocorrentes no litoral da Ilha do Maranhão, descrições, ilustrações e comentários sobre semelhanças morfológicas com base em caracteres reprodutivos e vegetativos. Além de dados de distribuição fitogeográfica e informações sobre a fenologia reprodutiva, que foram obtidos a partir de observações realizadas em campo e das informações disponíveis nas fichas das exsicatas.

\section{RESULTADOS E DISCUSSÃO}

A família Myrtaceae está representada por 16 espécies e distribuídas em seis gêneros no litoral da Ilha do Maranhão. Os gêneros Eugenia L. (com sete espécies) e Myrcia DC. (com cinco) foram os mais representativos em número de espécies, seguidos de Calycolpus O. Berg, Campomanesia Ruiz et Pav., Myrciaria O. Berg e Psidium L. com uma espécie, cada. A seguir é apresentado o tratamento taxonômico e chave de identificação para as espécies ocorrentes nas áreas de dunas e restingas da Ilha do Maranhão.

Myrtaceae Juss. Gen. P1. 322-323. 1789.

Árvore ou subarbusto; ramos cilíndricos com ritidoma. Folha simples, oposta, pontuações translúcidas presentes, estípula ausente. Flor diclamídea, monoclina, actinomorfa, solitária ou reunida em dicásio, racemo, fascículo, glomérulo ou panícula. Bráctea e bractéolas persistentes ou caducas. Pedicelo canaliculado ou não. Botão floral aberto ou fechado. Cálice 4-5-mero, lobos regulares ou irregulares, persistentes ou caducos; corola 5-mera, alva; androceu polistêmone; ovário ínfero, 2-5(pluri)-locular, pluriovulado. Fruto baga, globoso a elipsoide, pontuados ou não.

\section{Chave de identificação das espécies Myrtaceae ocorrentes nas dunas e restingas da Ilha do Maranhão}

1. Ovário 2-locular.

2. Cálice 5-mero; flores reunidas em panículas.

3. Ramo pubescente, com indumento ferrugíneo ou dourado.

4. Lâmina foliar largo-elíptico a orbicular, cartáceo a coriáceo, pubescente, indumento ferrugíneo; botão floral campanulado; fruto globoso Myrcia cuprea

4'. Lâmina foliar estreito-elíptico a lanceolado, cartáceo, glabrescente adaxialmente e pubescente abaxialmente, indumento dourado; botão floral globoso; fruto elipsoide Myrcia splendens

3'. Ramo glabrescente, quando presente, indumento esbranquiçado.

5. Nervuras secundárias arqueadas; lobos do cálice deltoides e reflexos no fruto. Myrcia selloi

5'. Nervuras secundárias não arqueadas; lobos do cálice orbiculares e não reflexos no fruto

Myrcia multiflora

2'. Cálice 4-mero; flores reunidas em racemo, fascículo ou glomérulo.

6. Lobos do cálice caducos, permanecendo apenas a cicatriz no fruto Myrciaria tenella 6'. Lobos do cálice persistentes.

7. Ramo pubescente ou pubérulo, indumento esbranquiçado.

8. Lâmina foliar com ápice apiculado; presença de nervura intramarginal; margem revoluta

Eugenia biflora

8'. Lâmina foliar com ápice não apiculado; ausência de nervura intramarginal; margem não revoluta. 
9. Lâmina foliar concolor, glabra; nervura central plana a proeminente adaxialmente.

10.Lobos do cálice regulares; frutos globosos Eugenia flavescens

10'. Lobos do cálice irregulares; frutos elipsoides Eugenia punicifolia

9'. Lâmina foliar discolor, pubescente; nervura central sulcada adaxialmente......... Eugenia polystachya 7'. Ramo glabro.

11. Lâmina foliar com nervura intramarginal presente; pontuações translúcidas marcadas no pedicelo, bractéola, lobos do cálice e pétalas Eugenia stictopetala

11'. Lâmina foliar com nervura intramarginal ausente; pontuações translúcidas pouco visíveis no pedicelo, bractéola, lobos do cálice e pétalas.

12. Flores em fascículo; pedicelo de pubérulo a glabro, 5-10 mm compr.; lobos do cálice ovados

Eugenia protenta

12'. Flores em racemo; pedicelo pubescente, $2-4 \mathrm{~mm}$ compr.; lobos do cálice orbiculares

Eugenia densiracemosa

1'. Ovário 3 ou pluri-locular

13. Flores reunidas em panículas

Myrcia guianensis

13’. Flores solitárias ou reunidas em dicásios ou fascículos

14. Nervura marginal presente Calycolpus goetheanus

14'. Nervura marginal ausente

15. Lâmina foliar estreito-elíptica, largo-elíptica a ovada, membranácea, levemente discolor; botão floral globoso Campomanesia aromatica

15'. Lâmina foliar elíptica, oblonga a ovada, cartácea, concolor; botão floral piriforme ...... Psidium guajava

Calycolpus goetheanus (Mart. ex DC.) O. Berg, Linnaea 27: 381. 1856.

\section{(Fig. 2 A-D)}

Árvore 2,5-6 m alt. Ramo descamante, pubérulo a glabro, indumento esbranquiçado. Folha 3,6-22 x 2,7-9,5 $\mathrm{cm}$, elíptica, largo-elíptica, obovada a ovada, cartácea a membranácea, discolor, glabra, base rotunda a cuneada, ápice agudo a longo-acuminado, margem plana; nervura central sulcada ou impressa adaxialmente, nervuras secundárias visíveis, 10-20 pares, nervura marginal simples; pontuações translúcidas visíveis; pecíolo 1-7 mm compr., pubérulo, canaliculado ou levemente canaliculado. Flores solitárias ou reunidas em fascículo, axilar e terminal, 1-5 flores, raque ausente. Bráctea 0,3 x 0,6 mm, deltoide, ápice agudo, persistente. Pedicelo 9-33 mm compr., glabro. Bractéola $0,5-0,8 \times 0,3-0,7 \mathrm{~mm}$, lanceolada, ápice agudo, persistente. Botão floral aberto, 7 x $12 \mathrm{~mm}$, globoso. Cálice 5-mero, lobos regulares 5-7 x 4-5 mm, ovado, glabro; ovário 3-5-locular. Fruto $0,7 \times 1,1 \mathrm{~cm}$, globoso, glabro, lobos do cálice persistentes e não reflexos.

Material selecionado: BRASIL, MARANHÃO, São José de Ribamar, praia de Panaquatira, 25.VII.2015, G.P. Lima 614 (MAR); Sítio Aguahy, 28.VIII.2012, F.C.V. Serra 78 (MAR); 07.V.2016, G.S. Amorim 266 (MAR); 25.VIII.2017, G.S. Amorim 361 (MAR); 28.X.2017, G.S. Amorim 376(MAR); 28.X.2017, G.S. Amorim 378(MAR); 03.II.2018, G.S. Amorim 445 (MAR). São Luís, praia de São Marcos, 10.XI.2017, G.S. Amorim 390 (MAR).
Calycolpus goetheanus ocorre no Brasil, Guiana Francesa, Suriname, Guiana, Venezuela e Colômbia (Global Biodiversity Information Facility - GBIF 2017). No Brasil pode ser encontrada nos estados do Amazonas, Pará e Maranhão com ocorrência em área de Floresta Amazônica e no Cerrado (BFG 2015). No litoral da Ilha do Maranhão, essa espécie foi encontrada nas dunas da praia de São Marcos e na restinga da praia de Panaquatira e do Sítio Aguahy. As flores ocorrem ao longo de todo ano com pico de floração em novembro, janeiro e abril (Landrum 2010). Na Ilha do Maranhão a floração foi registrada em julho, agosto e outubro e frutificação em agosto, outubro e novembro.

Essa espécie apresenta flores solitárias ou reunidas em fascículos, com pedicelos compridos (alcançando até $3,3 \mathrm{~cm}$ ) e frutos globosos e enegrecidos quando maduro. Depois de herborizada a nervura central e as secundárias ficam enegrecidas, e por vezes a lâmina foliar tem aspecto lustroso adaxialmente e mais escura abaxialmente.

Campomanesia aromatica (Aubl.) Griseb., Fl. Brit. W.I. [3]: 242 (1860).

(Fig. 2 E-F)

Arbusto 1,5-2 m alt. Ramo não descamante, pubérulo a glabro, indumento esbranquiçado. Folha 3,4-10,2 x 1,1-6,9 cm, estreito-elíptica, largo-elíptica a ovada, membranácea, levemente discolor, pubescente, indumento esbranquiçado, base arredondada a cuneada, ápice agudo 


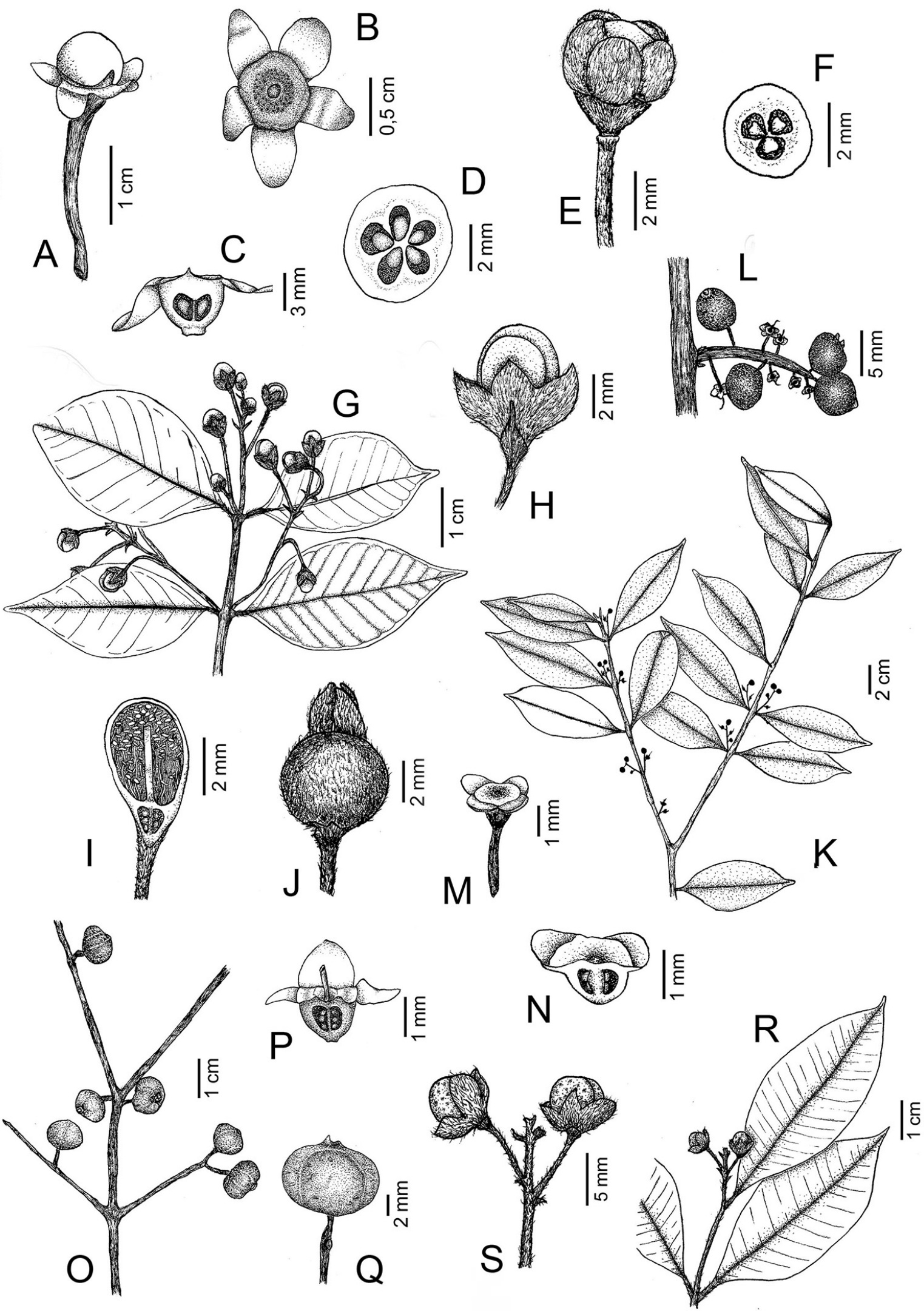

Figura 2. A-S. Ilustração morfológica das espécies. A-D. Calycolpus goetheanus. A. Botão floral; B. Disco estaminífero e lobos do cálice; C. Corte longitudinal no ovário; D. Corte transversal no ovário. E-F. Campomanesia aromatica. E. Botão floral; F. Corte transversal no ovário. G-J. Eugenia biflora. G. Hábito; H. Botão floral; I. Corte longitudinal no botão floral; J. Fruto. K-N. Eugenia densiracemosa. K. Hábito; L. flores passadas e frutos imaturos; M. Disco estaminífero e lobos do cálice; N. Corte longitudinal no ovário. O-Q. Eugenia flavescens. O. Ramo com frutos; P. Corte longitudinal no ovário; Q. Fruto. R-S. Eugenia polystachya. R. Hábito; S. Inflorescência. 
a curto acuminado, margem plana; nervura central plana adaxialmente, nervuras secundárias visíveis, impressas e nigrescente abaxialmente 5-12 pares, nervura marginal ausente; pontuações translúcidas visíveis; pecíolo 5-13 mm compr., pubérulo, pubescente em folhas jovens, canaliculado, com o canal indo até a metade do pecíolo. Flor solitária, axilar, uma por axila, raque inconspícua. Bráctea não observada. Pedicelo 3-30 mm compr., pubescente. Bractéola 2,8-3 x 0,2-0,3 mm, estreito-lanceolada, ápice agudo, decídua. Botão floral aberto, 3,2-3,9 x 3-3,5 mm, globoso. Cálice 5-mero, lobos regulares 1,6-5 x 3,5-3,7 $\mathrm{mm}$, deltoide, pubescente; ovário 3-7-locular. Fruto 0,7-1,1 x 0,5-1 cm, globoso, pubérulo, lobos do cálice persistentes e não reflexos.

Material selecionado: BRASIL, MARANHÃO, São José de Ribamar, praia de Caúra, 13.I.2017, G.S. Amorim 507 (MAR). São Luís, praia de São Marcos, 14.IV.2018, G.S. Amorim 497 (MAR); 12.I.2019, G.S. Amorim 517 (MAR). 12.I.2019, G.S. Amorim 518 (MAR).

Campomanesia aromatica tem distribuição no Caribe, Brasil, Guiana Francesa, Suriname, Guiana, Venezuela, Bolívia e Paraguai (GBIF 2017). No Brasil tem ocorrência confirmada para as regiões Norte (Roraima, Amapá, Amazonas, Pará) e Nordeste (Maranhão, Ceará, Rio Grande do Norte, Paraíba e Bahia), em área de Floresta Amazônica, Caatinga e Mata Atlântica (Landim \& Landrum 2002, BFG 2015). No litoral da Ilha do Maranhão foi encontrada nas áreas de dunas da praia de São Marcos e restinga da praia de Caúra. Tem registro de floração em junho e novembro e a frutificação em outubro (Luber et al. 2017), e nas áreas de restinga da Ilha do Maranhão a floração e frutificação foi registrada em janeiro.

Essa espécie tem ramos e lâmina foliar pubescente, com indumento esbranquiçado e esparso. Tem nervura marginal ausente e pontuações translúcidas fortemente marcadas e nigrescente. Segundo Landrum (1986) o fruto pode apresentar coloração enegrecida quando maduro.

\section{Eugenia biflora (L.) DC., Prodr. 3: 276. 1828.}

\section{(Fig. 2 G-J)}

Árvore a arbusto 1,9-5 m alt. Ramo não descamante, densamente pubescente, indumento esbranquiçado. Folha $1,8-7,8 \times 0,5-3,1 \mathrm{~cm}$, elíptica, estreito-elíptica, lanceolada a ovada, cartácea, concolor, pubescente, indumento esbranquiçado, base arredondada, cuneada a atenuada, ápice agudo a longo acuminado, sempre apiculado, margem revoluta; nervura central impressa adaxialmente, nervuras secundárias visíveis somente abaxialmente, $12-13$ pares, nervura marginal dupla; pontuações translúcidas pouco visíveis; pecíolo 2-4,4 $\mathrm{mm}$ compr., densamente pubescente, canaliculado. Flores reunidas em racemo, axilar, às vezes dois racemos por axila, 1-20 flores, raque $15-25 \mathrm{~mm}$ compr. Bráctea $1 \times 4,5 \mathrm{~mm}$, elíptica a lanceolada, ápice agudo, persistente. Pedicelo 3-19 mm compr., pubescente. Bractéola ca. 2 × $5 \mathrm{~mm}$, orbicular a lanceolada, ápice acuminado a arredondado, persistente. Botão floral fechado, $3 \times 4 \mathrm{~mm}$, globoso. Cálice 4-mero, lobos regulares $2 \times$ $3 \mathrm{~mm}$, orbicular, pubescente; ovário 2-locular. Fruto $0,6-0,8 \times 0,4-0,6 \mathrm{~cm}$, globoso, pubescente, lobos do cálice persistentes e não reflexos.

Material selecionado: BRASIL, MARANHÃO, São José de Ribamar, praia de Panaquatira, 23.I.2014, E.B. Almeida Jr. 1070 (MAR). Sitio Aguahy, 28.IX.2015, G.S. Amorim 281 (MAR). São Luís, praia da Guia, 13.XI.2015, G.S. Amorim 321 (MAR); 26.X.2016, G.S. Amorim 332 (MAR); 04.II.2017, G.S. Amorim 303 (MAR); praia de São Marcos, 12.I.2013, A.N.F. Silva 748 (MAR); 02.VIII.2014, A.N.F. Silva 437 (MAR); 21.XI.2015, A.N.F. Silva 705 (MAR); Praia do Caolho, 13.VI.2018, G.S. Amorim 495 (MAR). Paço do Lumiar, praia de Araçagi, 24.I.2015, G.S. Amorim 36 (MAR); 11.IX.2015, G.S. Amorim 217 (MAR); 07.XI.2015, G.S. Amorim 231 (MAR); Raposa: Ilha de Curupu, 01.XI.2014, M.A. Machado 83 (MAR).

Eugenia biflora tem ampla distribuição, com ocorrência para o México, Belize, Guatemala, Honduras, El Salvador, Costa Rica, Caribe, Brasil, Guiana Francesa, Guiana, Colômbia, Equador e Bolívia (GBIF 2017). No Brasil possui ocorrência para o Norte, Nordeste (Maranhão e Piauí) e Centro-Oeste, em área de Floresta Amazônica, Caatinga e Cerrado (BFG 2015). No litoral da Ilha do Maranhão essa espécie foi encontrada em todas as áreas com uma ampla variação na morfologia foliar. A floração foi registrada nos meses de janeiro, agosto, setembro, outubro e novembro e a frutificação em janeiro, fevereiro, agosto, setembro, outubro e novembro.

A sua ampla distribuição, variações na pubescência da lâmina foliar e no tamanho dos botões florais podem justificar as várias sinonímias. Essa espécie pode ser reconhecida pela presença de indumento esbranquiçado no ramo, lâmina foliar, inflorescência e fruto. A lâmina foliar tem ápice sempre apiculado, margem revoluta e nervuras secundárias visíveis somente abaxialmente.

\section{Eugenia densiracemosa Mazine \& Faria, Phytotaxa,} 151: 53, 2013.

\section{(Fig. 2 K-N)}

Arbusto 0,5-2 m alt., Ramo não descamante, glabro. Folha 2,5-12 x 1,8-5 cm, elíptica a estreito elíptica, subcoriácea a coriácea, discolor, glabra, base cuneada, ápice agudo a curto acuminado, margem levemente revoluta; nervura central plana adaxialmente, nervuras secundárias visíveis somente abaxialmente, 8-12 pares, nervura marginal simples; pontuações translúcidas visíveis; pecíolo 2-7 mm compr., glabrescente, canaliculado. Flores reunidas em racemo, axilar, 7-15 flores, raque 1,8-3 $\mathrm{mm}$ compr. Bráctea $0,2 \times 0,3 \mathrm{~mm}$, ovado, ápice agudo a arredondado, persistente. Pedicelo 2-4 $\mathrm{mm}$ compr. pubescente. Bractéola $0,2 \times 0,5 \mathrm{~mm}$, ovado, ápice agudo a obtuso, persistente. Botão floral não observado. Cálice 4-mero, lobos irregulares, $0,3-0,4 \times 0,5-0,6 \mathrm{~mm}$ nos 
lobos menores e $0,5-0,7 \times 0,5-0,6 \mathrm{~mm}$ nos lobos maiores, orbicular, glabro; ovário 2-locular. Fruto 1,1 x 1,7 cm, globoso, glabro, lobos do cálice persistentes e não reflexos.

Material selecionado: BRASIL, MARANHÃO, São José de Ribamar, Sítio Aguahy, 25.VIII.2017, G.S. Amorim 459 (MAR); 28.X.2017, G.S. Amorim 379 (MAR); São Luís, praia de São Marcos, 24.I.2018, G.S. Amorim 411 (MAR).

Eugenia densiracemosa ocorre no Brasil, Guiana Francesa e Guiana (Mazine \& Faria 2013, GBIF 2017). No Brasil tem registro para as regiões Norte (Acre, Pará, Tocantins), Nordeste (Maranhão e Ceará) e Centro-Oeste (Mato Grosso e Goiás) em área de Floresta Amazônica e no Cerrado (BFG 2015). A floração ocorre de outubro a maio e a frutificação em março, julho, agosto e novembro (Mazine \& Faria 2013). No litoral da Ilha do Maranhão foi encontrada na praia de São Marcos com frutificação registrada em outubro.

Essa espécie apresenta ramo e lâmina foliar glabros. A lâmina foliar é subcoriácea e discolor, com nervura central sulcada adaxialmente. Nos espécimes analisados o racemo apresentou raque bastante reduzida, com 1,8-3 mm compr., no entanto, em outros estudos já foi observado até $6,2 \mathrm{~mm}$ (Trindade et al. 2018, Mazine \& Faria 2013). Quando maduros os frutos apresentam de coloração alaranjada.

\section{Eugenia flavescens DC., Prodr. 3: 272. 1828.}

(Fig. 2 O-Q)

Arbusto 0,5-2,5 m alt. Ramo não descamante, indumento esbranquiçado, pubérulo. Folha 2,3-10,4 x 1,1-5,1 cm, elíptica, largo-elíptica, oblonga a oblanceolada, subcoriácea, concolor, glabra, base arredondada a cuneada, ápice agudo a acuminado, margem plana; nervura central plana a proeminente adaxialmente, nervura secundária pouco visível, 6-16 pares, nervura marginal simples; pontuações translúcidas visíveis; pecíolo 2,3-7 mm compr., pubérulo, canaliculado. Flores reunidas em fascículo, axilar e caulinar, 1-7 flores, raque até $1 \mathrm{~mm}$ compr. Bráctea 0,5 x $0,7 \mathrm{~mm}$, arredondada, ápice agudo, persistente até a frutificação. Pedicelo 1,6-2 mm compr., glabro. Bractéola $0,7 \times 1,5 \mathrm{~mm}$, ovada a orbicular, ápice agudo a arredondado, persistente. Botão floral não observado. Cálice 4-mero, lobos regulares 1,4-2 x 1,9-2,4 mm, deltoide a orbicular, glabrescente; ovário 2-locular. Fruto 0,4-0,9 x 0,6-1,5 $\mathrm{cm}$, globoso, glabrescente, lobos do cálice persistentes e não reflexos.

Material selecionado: BRASIL, MARANHÃO, Alcântara, praia de Itatinga, 20.VII.2013, B.E.F. Correia 985 (MAR). 20.VII.2013, B.E.F. Correia 986 (MAR). 24.II.2018, E.B. Almeida Jr. 1481 (MAR). São Luís, praia de São Marcos, 14.IV.2018, G.S. Amorim 500 (MAR).

Eugenia flavescens tem distribuição no Brasil, Guiana Francesa, Suriname, Guiana, Venezuela, Equador, Colômbia, Bolívia, Paraguai e Argentina (GBIF 2017). Ocorre em quase todo território brasileiro (exceto na região Sul, nos estados de Paraíba, Alagoas, Sergipe, Distrito
Federal e Espirito Santo) em área de Floresta Amazônica, Caatinga, Cerrado e Mata Atlântica (BFG 2015). No litoral da Ilha do Maranhão foi encontrada nas dunas da praia de São Marcos, com período de frutificação registrado no mês de julho.

Essa espécie tem lâmina foliar e pedicelo de coloração amarelada após o processo de herborização, o que pode ajudar no reconhecimento da espécie na ausência de material reprodutivo. A nervura central é plana a proeminente adaxialmente, a inflorescência do tipo fascículo, com flores diminutas, e frutos com pontuações fortemente marcados cobrindo toda a superfície.

Eugenia polystachya Rich., Actes Soc. Hist. Nat. Paris 1: 110. 1792.

(Fig. 2 R-S)

Arbusto ca. 2,5 m alt. Ramo não descamante, pubescente, com indumento esbranquiçado. Folha 4,9-7,5 x 1,5-3,1 $\mathrm{cm}$, elíptica, cartácea, discolor, glabra adaxialmente e densamente pubescente abaxialmente, indumento esbranquiçados, base cuneada, ápice agudo a acuminado, margem plana; nervura central impressa adaxialmente, nervuras secundárias visíveis somente abaxialmente, 31-35 pares, nervura marginal simples; pecíolo 5-6 $\mathrm{mm}$ compr., pubescente, canaliculado. Flores reunidas em racemo, terminal, $1-5$ flores, raque $10-16 \mathrm{~mm}$ compr. Bráctea 0,5 x $2 \mathrm{~mm}$, lanceolada, ápice agudo, persistente. Pedicelo ca. $10 \mathrm{~mm}$ compr., pubescente. Bractéola ca. $2 \mathrm{~mm}$, deltoide a orbicular, ápice arredondado, persistente. Botão floral aberto, $5 \times 7 \mathrm{~mm}$, globoso. Cálice 4-mero, lobos irregulares ca. $3 \mathrm{~mm}$ nos lobos menores e ca. $5 \mathrm{~mm}$ nos lobos maiores, orbicular; ovário 2-locular. Fruto não observado.

Material selecionado: BRASIL, MARANHÃO, São Luís, dunas da praia de São Marcos, 24.I.2018, G.S. Amorim 410 (MAR)

Eugenia polystachya tem ocorrência confirmada no Brasil, Guiana Francesa, Suriname, Guiana e Bolívia (Tropicos 2018). No Brasil tem distribuição restrita em área de Floresta Amazônica, no Norte (Acre, Amazonas, Amapá, Pará, Roraima) e Nordeste (Maranhão) (BFG 2015). No litoral da Ilha do Maranhão foi encontrada na praia de São Marcos, em um local de difícil acesso, em meio a uma vegetação mais fechada, com a floração registrada em janeiro.

Essa espécie pode ser reconhecida pelo ramo pubescente, com indumento esbranquiçado, lâmina foliar discolor com nervura central sulcada adaxialmente e nervuras secundárias visíveis somente abaxialmente, lobos do cálice irregulares e densamente pubescente com indumento esbranquiçado.

Eugenia protenta McVaugh, Mem. New York Bot. Gard., 18(2): 204, 1969.

(Fig. 3 A-C)

Arbusto ca. $3 \mathrm{~m}$ alt. Ramo não descamante, glabro. Folha 4,9-11,5 x 2,1-4,9 cm, elíptica a largo-elíptica, cartácea, 
levemente discolor, glabrescente, base arredondada a cuneada, ápice agudo a longo acuminado, margem plana; nervura central sulcada adaxialmente, nervuras secundárias visíveis somente abaxialmente, 10-13 pares, nervura marginal simples; pontuações translúcidas pouco visíveis; pecíolo 3-6 mm compr., pubérulo a glabrescente, levemente canaliculado a canaliculado. Flores reunidas em fascículo, axilar, 1-12 flores, raque 1,3-2,5 mm compr. Bráctea 0,2 x $0,5 \mathrm{~mm}$, obovadas a orbicular, ápice agudo, persistente. Pedicelo 5-10 mm compr., pubérulo a glabro. Bractéola 0,5 x 1,2 mm, orbicular, ápice agudo, persistente. Botão floral não observado. Cálice 4-mero, lobos irregulares 1,2-1,7 x 1,2-2 mm compr. nos menores e 1,7-2,1 x 1,7-3 mm compr. nos maiores, ovado, pubérulo a glabro; ovário 2-locular. Fruto $0,6-1 \times 0,6-0,8 \mathrm{~cm}$, globoso a elíptico, pubescente, lobos do cálice persistentes e não reflexos.

Material selecionado: BRASIL, MARANHÃO, São Luís, praia de São Marcos, 14.IV.2018, G.S. Amorim 502 (MAR). São José de Ribamar, Sítio Aguahy, 25.VIII.2017, G.S. Amorim 362 (MAR); 28.X.2017, G.S. Amorim 375 (MAR).

Eugenia protenta tem ocorrência no Brasil, Guiana, Venezuela, Colômbia, Peru e Bolívia (GBIF 2017). No Brasil tem ocorrência confirmada na região Norte (Acre, Amazonas, Pará, Rondônia) e Nordeste (Maranhão) (BFG 2015), com distribuição restrita a área de Floresta Amazônica. No litoral da Ilha do Maranhão foi encontrada em uma área das dunas da praia de São Marcos. Sua floração foi registrada em agosto e frutificação em outubro.

Essa espécie pode ser reconhecida pela inflorescência do tipo fascículo com longos pedicelos, por vezes, maiores que a raque da inflorescência. Tem frutos globosos de coloração preta quando maduro, e pode ser encontrado de coloração laranja, dependendo do tempo de maturação.

Eugenia punicifolia (Kunth) DC., Prodr. 3: 267. 1828.

(Figs. 3 D-G)

Arbusto 0,5-1,5 m alt. Ramo não descamante, pubescente, indumento esbranquiçado a castanho. Folha 1,1-13,3 x 1,2$5,4 \mathrm{~cm}$, ovada, obovada a largo elíptica, cartácea, concolor, glabra, base cuneada, ápice agudo a acuminado, margem plana; nervura central plana a proeminente adaxialmente, nervuras secundárias visíveis, 6-12 pares, nervura marginal simples; pontuações translúcidas visíveis; pecíolo ca. 3 mm compr., glabro a pubescente, levemente canaliculado. Flores reunidas em fascículo, às vezes reduzidas a duas flores por axilas, axilar, 2-8 flores, raque inconspícua. Bráctea 0,6 x 3,9 mm, lanceolada, ápice agudo, persistente. Pedicelo 10-26 mm compr., glabro. Bractéola 0,3 x 2 $\mathrm{mm}$, orbicular a lanceolada, ápice agudo a arredondado, persistente. Botão floral fechado, 3,4 x 6,1 mm, globoso. Cálice 4-mero, lobos irregulares 1,5-2,9 x 1,5-2,1 mm nos lobos menores e 2,5-3 x 2,1-2,5 mm nos lobos maiores, orbicular a oblongo, glabro; ovário 2-locular. Fruto 0,6-1,1 x 0,5-1,3 cm, elipsoide, glabro, lobos do cálice persistentes e não reflexos.
Material selecionado: BRASIL, MARANHÃO, São José de Ribamar, praia de Panaquatira, 02.VIII.2014, G.P. Lima 386 (MAR); 29.III.2014, G.P. Lima 148 (MAR). Sitio Aguahy, 07.V.2016, G.S. Amorim 268 (MAR); 07.V.2016, G.S. Amorim 300 (MAR). São Luís, praia de Guia, 26.VIII.2015, G.S. Amorim 322 (MAR); praia de São Marcos, 14.VI.2018, G.S. Amorim 503 (MAR); praia de Caolho, 13.VI.2018, G.S. Amorim 494 (MAR). Paço do Lumiar, praia do Araçagi, 11.IX.2015, G.S. Amorim 250 (MAR); 07.XI.2015, G.S. Amorim 238 (MAR).

Eugenia punicifolia possui ocorrência de Cuba até o sul da América do Sul (Govaerts et al. 2008) e é amplamente distribuída no Brasil, em área de Floresta Amazônica, Caatinga, Cerrado e Mata Atlântica (BFG 2015). No litoral da Ilha do Maranhão, foi encontrada nas dunas das praias do Araçagi, Guia e São Marcos e nas restingas das praias de Panaquatira e do Sitio Aguahy, com floração registrada em julho e setembro e frutificação em janeiro, julho, agosto, setembro e novembro.

Essa espécie apresenta ampla variação foliar e pode ser reconhecida por apresentar flores reunidas em fascículo, às vezes reduzidas a duas flores por axilas, com pedicelos compridos, nervura marginal simples, afastada e quase paralela a margem. Os frutos são elipsoides e de coloração avermelhada ou alaranjada quando maduros, o que pode variar de acordo com o tempo de maturação.

\section{Eugenia stictopetala DC., Prodr. 3: 270. 1828.}

(Fig. 3 H-J)

Arbusto 0,5-4 m alt. Ramo descamante, glabro. Folha 2,8-18,1 x 1,7-9 cm, elíptica, largo-elíptica, oblonga, oval a rotunda, cartácea, concolor, glabra, base cuneada a rotunda, ápice agudo a arredondado, margem plana; nervura central levemente impressa na porção proximal a plana na porção distal adaxialmente, nervuras secundárias visíveis, 5-15 pares, nervura intramarginal presente; pontuações translúcidas, marcadas no pedicelo, bractéola, lobos do cálice e pétala; pecíolo 3-10 mm compr., glabro, canaliculado. Flores reunidas em fascículo, axilar e caulinar, 2-12 flores, raque inconspícua. Bráctea $0,6 \times 2,4 \mathrm{~mm}$, orbicular, ápice agudo a arredondado, persistente. Pedicelo 2,8-19 mm compr., pubescente a glabro. Bractéola 0,7 x $5 \mathrm{~mm}$, elíptica a oblonga, ápice agudo a arredondado, persistente. Botão floral aberto, 3,3 x $7 \mathrm{~mm}$, globoso. Cálice 4-mero, lobos regulares 0,8-2,5 x 1,5-2,3 mm, orbicular, glabrescente a pubescente; ovário 2-locular. Fruto $0,9-1,7 \times 0,6-1,3 \mathrm{~cm}$, globoso, glabro, lobos do cálice persistentes e não reflexos.

Material selecionado: BRASIL, MARANHÃO, São José de Ribamar, restinga do Sítio Aguahy, 07.V.2016, G.S. Amorim 279 (MAR). Restinga da praia de Panaquatira, 29.III.2014, P.G. Lima 147 (MAR). São Luís, dunas da praia Guia, 26.VII.2015, A.V.F. Guterres 61 (MAR); 26.X.2016, B.H.I. Paiva 43 (MAR); 26.X.2016, B.H.I. Paiva 70 (MAR); 26.X.2016, G.S. Amorim 338 (MAR). 


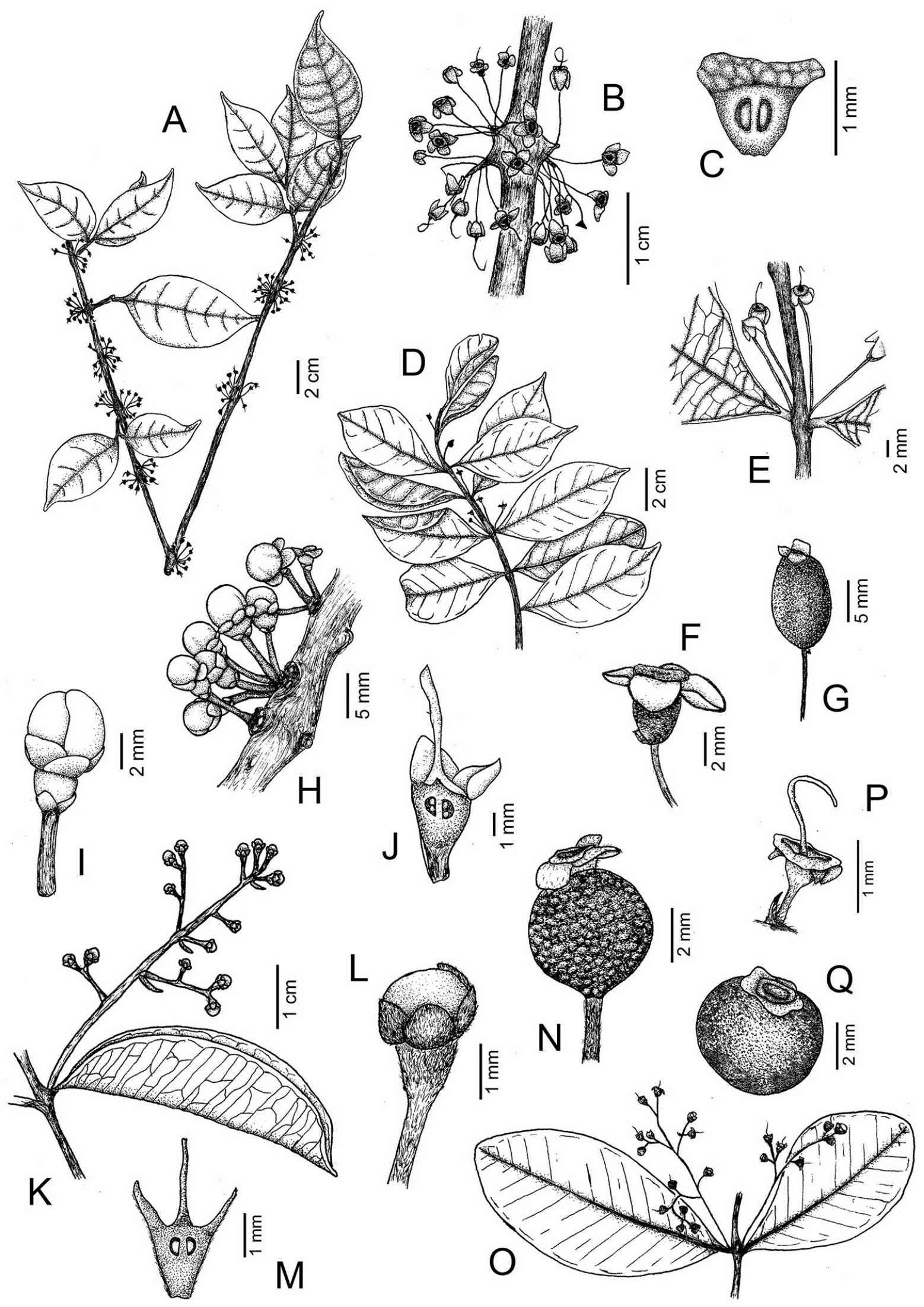

Figura 3. A-Q. Ilustração morfológica das espécies. A-C. Eugenia protenta. A. Hábito; B. Flores passadas; C. Corte longitudinal no ovário. D-G. Eugenia punicifolia. D. Hábito; E. Flores solitárias, às vezes duas por axila; F. Flor passada; G. Fruto elipsoide. H-J. Eugenia stictopetala. H. Inflorescência; I. Botão floral; J. Corte longitudinal no ovário. K-N. Myrcia cuprea. K. Hábito; L. Botão floral; M. Corte longitudinal no ovário; N. Fruto. O-Q. Myrcia guianensis. O. Hábito; P. Flor passada; Q. Fruto. 
Dunas da praia de São Marcos, A.N.F. Silva 749 (MAR); 12.I.2013, A.N.F. Silva 750 (MAR); 10.XI.2017, G.S. Amorim 387 (MAR); 10.XI.2017, G.S. Amorim 388(MAR); 22.II.2017, G.S. Amorim 341 (MAR); 14.VI.2018, G.S. Amorim 506 (MAR).

Eugenia stictopetala tem ocorrência no Brasil, Guiana Francesa, Suriname, Guiana, Colômbia, Bolívia e Paraguai (GBIF 2017). No Brasil possui ampla distribuição em todo território, em área de Floresta Amazônica, Caatinga, Cerrado e Mata Atlântica (BFG 2015). No litoral da Ilha do Maranhão foi encontrada nas dunas da praia da Guia e São Marcos e restinga da praia de Panaquatira e do Sítio Aguahy. A floração foi registrada nos meses de janeiro, agosto e dezembro e a frutificação nos meses de agosto e outubro.

Essa espécie pode ser reconhecida pela lâmina foliar cartácea com nervuras secundárias visíveis e pontuações translúcidas marcadas nos pedicelos, bractéolas, lobos do cálice e pétalas. $\mathrm{O}$ fruto tem coloração variando de laranja a vermelho, dependendo do tempo de maturação.

\section{Myrcia cuprea (O. Berg) Kiaersk., Enum. Myrt. Bras.: 95 (1893).}

(Fig. $3 \mathrm{~K}-\mathrm{N}$ )

Arbusto 1,3-2,5 m alt. Ramo não descamante, pubescente, indumento ferrugíneo. Folha 2,7-5,9 x 1,9-4,8 $\mathrm{cm}$, elíptica, largo-elíptica a orbicular, cartácea a coriácea, concolor, pubescente, base arredondada a cuneada, ápice agudo, arredondado, obtuso a cuspidado, margem plana; nervura central plana adaxialmente, nervuras secundárias visíveis, $8-12$ pares, nervura marginal simples; pontuações translúcidas visíveis; pecíolo 4-6 mm compr., pubescente, levemente canaliculado. Flores reunidas em panículas, axilar e terminal, 10-48 flores, raque 15-90 mm compr. Bráctea 4 x $6 \mathrm{~mm}$, lanceolada, ápice agudo, decídua. Pedicelo 0,5-1 $\mathrm{mm}$ compr. ou ausente, pubescente. Bractéola $0,5 \times 2 \mathrm{~mm}$, lanceolada, ápice agudo, decídua. Botão floral aberto, 2-3 x 1,8-2 mm, campanulado. Cálice 5-mero, lobos regulares $0,5 \times 1 \mathrm{~mm}$, orbicular, pubescente; ovário 2-locular. Fruto $0,6-0,8 \times 0,4-0,6 \mathrm{~cm}$, globoso, pubescente, lobos do cálice persistentes e não reflexos.

Material selecionado: BRASIL, MARANHÃO, São José de Ribamar, praia de Panaquatira, 19.VIII.2014, P.G. Lima 489 (MAR). São Luís, praia de São Marcos, 20.XII.2011, A.N.F. Silva 418 (MAR); 24.I.2018, G.S. Amorim 404 (MAR). Praia da Guia, 01.VIII.2017, G.S. Amorim 344 (MAR). Praia de Caolho, 13.IV.2013, G.S. Amorim 496 (MAR). Raposa, Ilha de Curupu, 17.XI.2017, M.A. Machado 101 (MAR).

Myrcia cuprea tem registro de ocorrência para o Brasil, Guiana Francesa, Suriname, Equador e Bolívia (GBIF 2017). No Brasil ocorre na região Norte (Amapá, Amazônia, Pará) e Nordeste (apenas o Maranhão), em área de Floresta Amazônica e Cerrado (BFG 2015). No litoral da Ilha do Maranhão foi encontrada nas dunas da praia da Guia e São
Marcos e restinga da praia de Panaquatira e Ilha de Curupu, com floração registrada entre meses de agosto e dezembro e a frutificação em novembro e fevereiro.

Essa espécie pode ser reconhecida por apresentar indumento ferrugíneo na lâmina foliar, principalmente em folhas jovens, inflorescência e botão floral. Tem fruto globoso, pubescente de coloração vermelha quando maduro.

\section{Myrcia guianensis (Aubl.) DC., Prodr., 3: 245 (1828).}

(Fig. 3 O-P)

Arbusto a árvore 3,5-6 m alt. Ramo não descamante, glabro. Folha 0,4-8,9 x 1-3,4 cm, elíptica, estreito-elíptica, obovada, oval a oblonga, membranácea a cartácea, concolor a discolor, glabrescente, base cuneada, ápice agudo, arredondado a obtuso, margem plana; nervura central plana abaxialmente, nervuras secundárias visíveis, 13-17 pares, nervura marginal simples; pontuações translúcidas visíveis; pecíolo 2-5 mm compr., glabrescente, não canaliculado. Flores reunidas em panícula, axilar e terminal, 1-20 flores, raque $13-83 \mathrm{~mm}$ compr. Bráctea $0,5 \times 1 \mathrm{~mm}$, lanceolada, ápice arredondado, caduca. Pedicelo 0,5-1,2 $\mathrm{mm}$ compr. glabrescente. Bractéola 0,5 x $1 \mathrm{~mm}$, lanceolada, ápice agudo, caduca. Botão floral aberto, 1 x $6 \mathrm{~mm}$, globoso ou obovado. Cálice 5-mero, lobos irregulares 1 x $2 \mathrm{~mm}$ nos lobos maiores e $0,5 \times 1 \mathrm{~mm}$ nos lobos menores, orbicular, glabrescente; ovário 3-locular. Fruto 0,3-0,4 x 0,4-0,7 cm, globoso, glabro, lobos do cálice persistentes e não reflexos.

Material selecionado: BRASIL, MARANHÃO, São José de Ribamar, Sitio Aguahy, 08.XII.2012, F.C.V. Serra 139 (MAR); 13.VII.2012, F.C.V. Serra 50 (MAR); 08.XII.2012, F.C.V. Serra 134 (MAR). Praia de Panaquatira, 01.VII.2017, G.A. Amorim 323 (MAR).

Myrcia guianensis tem ampla distribuição no Caribe, Panamá, Brasil, Guiana Francesa, Suriname, Guiana, Venezuela, Colômbia, Equador, Peru e Bolívia (GBIF 2017). Ocorre em todas as regiões brasileiras, em área de Floresta Amazônica, Caatinga, Cerrado e Mata Atlântica (BFG 2015). No litoral da Ilha do Maranhão foi registrada nas restingas do Sitio Aguahy e da praia de Panaquatira com floração em julho e dezembro e frutificação em julho.

Myrcia guianensis pode ser reconhecida por apresentar ramo glabro, frutos globosos, glabros e enegrecidos quando maduros. Após a herborização, essa espécie pode ser confundida, vegetativamente, com Myrcia cuprea, no entanto, esta última apresenta indumento ferrugíneo.

\section{Myrcia multiflora (Lam.) DC., Prodr., 3: 244 (1828).}

\section{(Fig. 4 D-E)}

Árvore a arbusto 2-2,5 m alt. Ramo descamante, glabro a glabrescente, indumento esbranquiçado. Folha 3-7,5 x 1-3,8 cm, elíptica, estreito-elíptica a ovada, membranácea, concolor, glabrescente, base cuneada, ápice agudo a acuminado, margem plana; nervura central impressa adaxialmente, nervuras secundárias visíveis, 1321 pares, nervura marginal simples; pontuações translúcidas 
visíveis; pecíolo 2-4 mm compr., glabro, pubescente apenas nos ramos jovens, não canaliculado. Flores reunidas em panícula, axilar e terminal, 20-21 flores, raque 28-31 $\mathrm{mm}$ compr. Bráctea 1 × $2 \mathrm{~mm}$, lanceolada, ápice agudo, decídua. Pedicelo 0,5-1,5 mm compr., glabro. Bractéola ca. $1 \mathrm{~mm}$, lanceolada, ápice arredondado, decídua. Botão floral aberto, 2-2,5 x 1,9-2 mm, globoso. Cálice 5-mero, lobos regulares $0,5 \times 1 \mathrm{~mm}$, orbicular, pubescente adaxialmente e glabrescente abaxialmente; ovário 2-locular. Fruto 2-3 x 1,5-5 cm, globoso, glabro, lobos do cálice persistentes e não reflexos.

Material selecionado: BRASIL, MARANHÃO, São José de Ribamar, restinga da praia de Panaquatira, 01.VII.2017, G.S. Amorim 326 (MAR); 01.VII.2017, G.S. Amorim 327 (MAR); 01.VII.2017, G.S. Amorim 328 (MAR). Raposa, restinga da Ilha de Curupu, 06.VI.2015, M.A. Machado s/n (MAR).

Myrcia multiflora tem registro de ocorrência no Brasil, Guiana Francesa, Suriname, Guiana, Venezuela, Colômbia, Peru, Bolívia e Paraguai (GBIF 2017). As espécies brasileiras ocorrem na região Norte (apenas Acre, Amazonas, Pará, Tocantins), Nordeste (apenas Maranhão, Rio Grande do Norte e Bahia), Centro-oeste, Sul e Sudeste, em área de Floresta Amazônica, Caatinga, Cerrado e Mata Atlântica (BFG 2015). No litoral da Ilha do Maranhão a espécie foi encontrada na praia de Panaquatira e na Ilha de Curupu. A floração foi registrada em julho, novembro e dezembro e frutificação em fevereiro e março.

Essa espécie pode ser reconhecida por apresentar lâmina foliar com ápice longo acuminado a caudado, membranácea com nervuras secundarias visíveis e nervura central impressa adaxialmente. Os frutos apresentam coloração enegrecida quando maduros.

\section{Myrcia selloi (Spreng.) N. Silveira, Loefgrenia 89:} 5 (1986): (1986).

\section{(Fig. 4 A-C)}

Arbusto 1,4-3 m alt. Ramo descamante, glabro a glabrescente, indumento esbranquiçado. Folha 0,9-6,2 x 1,2-2,9 cm, elíptica a estreito-elíptica, membranácea, concolor, glabrescente, base cuneada, ápice agudo a curto acuminado, margem plana; nervura central impressa adaxialmente, nervuras secundárias visíveis e arqueadas, 14-21 pares, nervura marginal simples; pontuações translúcidas visíveis; pecíolo ca. $2 \mathrm{~mm}$ compr., pubescente, canaliculado. Flores reunidas em panículas, axilar e terminal, 8-20 flores, raque $28-31 \mathrm{~mm}$ compr. Bráctea $0,5 \times 1 \mathrm{~mm}$, lanceolada, ápice agudo, decídua. Pedicelo $0,5-4,5 \mathrm{~mm}$ compr. glabrescente. Bractéola $0,5 \times 1 \mathrm{~mm}$, lanceolada, ápice agudo, persistente. Botão floral aberto, 1 x $3 \mathrm{~mm}$, globoso. Cálice 5-mero, lobos regulares $0,9 \times$ $1 \mathrm{~mm}$, deltoides, glabrescente adaxialmente e pubescente abaxialmente; ovário 2-locular. Fruto $0,3 \times 0,5 \mathrm{~cm}$, globoso, glabro, lobos do cálice persistentes e reflexos.
Material selecionado: BRASIL, MARANHÃO, São José de Ribamar, praia de Panaquatira, 02.VIII.2014, P.G. Lima 69 (MAR); 23.I.2015, E.B. Almeida Jr. 1071 (MAR). São Luís, praia de São Marcos, 24.I.2018, G.S. Amorim 407 (MAR). Raposa, Ilha do Curupu, 08.III.2015, M.A. Machado 131 (MAR). 07.III.2015, M.A. Machado 75 (MAR).

Myrcia selloi possui distribuição no Brasil, Peru, Bolívia, Paraguai e Argentina (GBIF 2017). No Brasil se distribui no Norte (Tocantins), Nordeste (Maranhão), Centro-Oeste, Sudeste (exceto Rio de Janeiro) e Sul (exceto Rio Grande do Sul), em área de Floresta Amazônica, Caatinga, Cerrado e Mata Atlântica (BFG 2015). No litoral da Ilha do Maranhão foi encontrada na restinga da Ilha de Curupu e na praia de Panaquatira e nas dunas da praia de São Marcos, com floração registrada em janeiro e março e frutificação em fevereiro.

Essa espécie é caracterizada por apresentar ramo glabro a glabrescente, lâmina foliar elíptica a estreitoelíptica, membranácea com nervuras secundárias visíveis e arqueadas. Os frutos apresentam coloração preta quando maduros e lobos do cálice reflexos (Santos \& Sano 2012). Alguns espécimes dessa espécie ainda podem ser encontrados nas coleções como M. larutotteana, que em uma revisão recente Myrcia sect. Tomentosae foi sinonimizada para M. selloi (De Lannoy et al. 2019).

\section{Myrcia splendens (Sw.) DC., Prodr., 3: 244 (1828).}

(Fig. 4 F-I)

Árvore ca. $2 \mathrm{~m}$ alt. Ramo não descamante, pubescente, indumento dourado. Folha 3-6,6 x 1,3-3 cm, elíptica, estreito-elíptica a lanceolada, cartácea, levemente discolor, glabrescente adaxialmente e pubescente abaxialmente, base cuneada, ápice agudo a longo acuminado, margem plana; nervura central plana adaxialmente, nervuras secundárias pouco visíveis, 21-34 pares, nervura marginal simples; pontuações translúcidas visíveis; pecíolo ca. $2 \mathrm{~mm}$ compr., pubescente, canaliculado. Flores reunidas em panícula, axilar e terminal, 20-30 flores, raque 18-45 $\mathrm{mm}$ compr. Bráctea $1 \times 2 \mathrm{~mm}$, lanceolada, ápice agudo, decídua. Pedicelo 0,5-1,5 mm compr. ou ausente, pubescente. Bractéola não observada, decídua. Botão floral aberto, 2-4,5 x 2,1-3 mm, globoso. Cálice 5-mero, lobos regulares 0,5 x $1 \mathrm{~mm}$, orbicular, glabrescente adaxialmente e pubescente abaxialmente; ovário 2-locular. Fruto $0,5-0,7$ x 0,4-0,5 $\mathrm{cm}$, elipsoide, pubescente, lobos do cálice persistente e não reflexo.

Material selecionado: BRASIL, MARANHÃO, São José de Ribamar, restinga da praia de Panaquatira, 25.I.2015, P.G. Lima 567 (MAR); 25.VII.2015, P.G. Lima 615 (MAR). Sítio Aguahy, 25.VIII.2017, G.S. Amorim 365 (MAR); 28.X.2017, G.S. Amorim 386 (MAR).

Myrcia splendens possui ocorrência no México, Guatemala, Costa Rica, Porto Rico, Caribe, Brasil, Guiana 


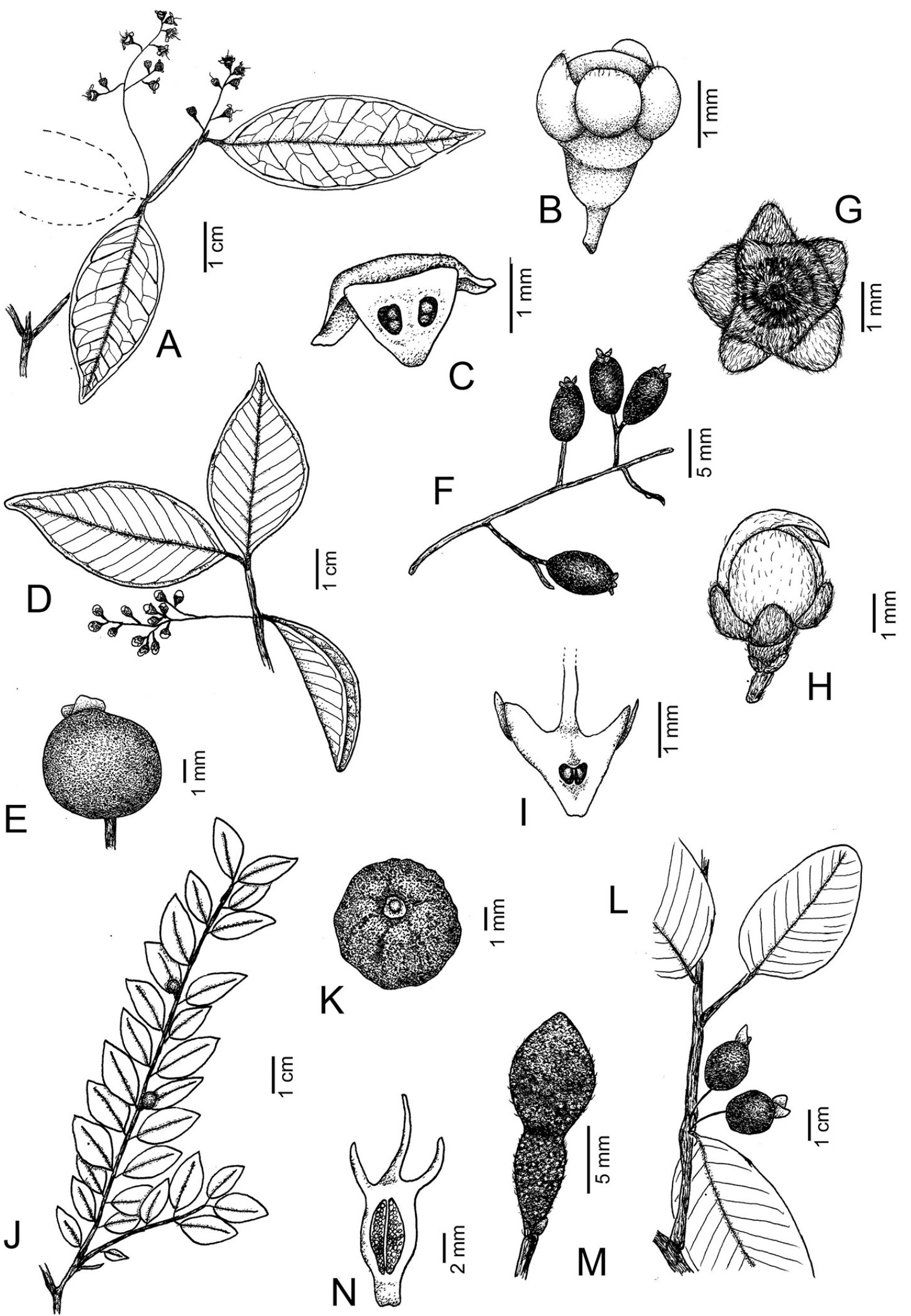

Figura 4. A-N. Ilustração morfológica das espécies. A-C. Myrcia selloi. A. Hábito; B. Botão floral; C. Corte longitudinal no ovário com lobos do cálice reflexos. D-E. Myrcia multiflora. D. Hábito; E. Fruto. F-I. Myrcia splendens. F. Ramo com frutos; G. Disco estaminífero e lobos do cálice; H. Botão floral; I. Corte longitudinal no ovário. J-K. Myrciaria tenella. J. Hábito; K. Fruto. L-N. Psidium guajava. L. Hábito; M. Botão floral piriforme; N. Corte longitudinal no ovário. 
Francesa, Guiana, Venezuela, Colômbia, Equador, Peru e Bolívia (GBIF 2017). No Brasil possui ampla distribuição, em área de Floresta Amazônica, Caatinga, Cerrado e Mata Atlântica (BFG 2015). No litoral da Ilha do Maranhão tem registro para a restinga de Panaquatira e Sítio Aguahy, com floração em outubro e dezembro e frutificação em janeiro.

Essa espécie tem ramos, inflorescência e fruto densamente pubescente, com indumentos dourados. Após a herborização, pode ser confundida, vegetativamente, com Eugenia biflora, ambas são pubescentes e podem apresentar lâmina foliar estreito-elíptico e ápice longo acuminado, entretanto, Myrcia splendens possui tricomas dourados e lâmina foliar com ápice nunca apiculado.

Myrciaria tenella (DC.) O. Berg, Fl. Bras. (Martius) 14(1): 179 (1857).

(Fig. $4 \mathrm{~J}-\mathrm{K}$ )

Árvore ca. 1,5 m alt. Ramo descamante, pubescente, indumento esbranquiçado. Folha $1-2,5 \times 0,5-1,2 \mathrm{~cm}$, elíptica, cartácea, levemente discolor, glabrescente, base cuneada, ápice agudo, margem plana; nervura central plana adaxialmente, nervuras secundárias pouco visíveis adaxialmente, $10-26$ pares, nervura marginal simples; pontuações translúcidas pouco visíveis; pecíolo 1-2 mm compr., pubescente, canaliculado. Flores reunidas em glomérulo, axilar e caulinar, 1-5 flores, raque inconspícua. Bráctea $0,3 \times 0,5 \mathrm{~mm}$, ovada a deltoide, ápice agudo, persistente. Pedicelo ausente. Bractéola $0,5 \times 1 \mathrm{~mm}$, ovada, ápice arredondado, decídua. Botão floral aberto, 2-2,1 x 1-2 mm, obovado. Cálice 4-mero, lobos regulares ca. 1 $\mathrm{mm}$, orbicular, glabrescente; ovário $2-$ locular. Fruto 0,4 x $0,5 \mathrm{~cm}$, globoso, glabro, lobos do cálice decíduos e não reflexos.

Material selecionado: BRASIL, MARANHÃO, São José de Ribamar, restinga do Sítio Aguahy, 07.VII.2016, G.S. Amorim 296 (MAR). 25.VIII.2017, G.S. Amorim 366 (MAR).

Myrciaria tenella ocorre no Haiti, República Dominicana, Brasil, Venezuela, Peru, Bolívia, Paraguai, Argentina e Uruguai (GBIF 2017). No Brasil tem registro de ocorrência para as regiões Norte (Pará), Nordeste (Maranhão e Bahia), Sudeste (exceto Espírito Santo) e Sul, em área de Floresta Amazônica, Caatinga, Cerrado e Mata Atlântica (BFG 2015). No litoral da Ilha do Maranhão foi encontrada somente na área de restinga do Sítio Aguahy com floração registrada em julho.

Essa espécie apresenta folhas diminutas e inflorescência em glomérulo, axilar e caulinar, com 1 a 5 flores. Depois da herborização tem nervura central com pequenas ondulações e as nervuras secundárias pouco visíveis adaxialmente. Tem fruto com lobos do cálice decíduo, o que auxilia na distinção das espécies do gênero Eugenia. Quando maduro os frutos apresentam coloração vermelha.
Psidium guajava L., Sp. Pl. 1: 470, 1753.

(Fig. $4 \mathrm{~L}-\mathrm{N}$ )

Árvore a arbusto 1,7-3 m alt. Ramo descamante, pubescente, indumento esbranquiçado. Folha 2,5-9,3 x $3,2-4,3 \mathrm{~cm}$, elíptica, oblonga a ovada, cartácea, concolor, pubescente, base atenuada, cuneada a arredondada, ápice agudo a arredondado, margem plana; nervura central sulcada adaxialmente, nervuras secundárias visíveis, 10-23 pares, nervura marginal ausente; pontuações translúcidas visíveis; pecíolo $2-5 \mathrm{~mm}$ compr., pubescente, canaliculado. Flores solitárias, eventualmente reunidas em dicásio, axilar e terminal, 1-3 flores, raque inconspícua a 21-25 mm compr. Bráctea $1 \times 2 \mathrm{~mm}$, lanceolada, ápice acuminado, decídua. Pedicelo $17-20 \mathrm{~mm}$ compr., densamente pubescente. Bractéola 1 × $3 \mathrm{~mm}$, lanceolada, ápice acuminado, decídua. Botão floral fechado, 2-4,5 x 2,1-3 mm, piriforme. Cálice 4-5-mero, lobos irregulares $10 \times 15 \mathrm{~mm}$, oblongo, pubescente; ovário 5-plurilocular. Fruto $0,8 \times 5,5 \mathrm{~cm}$, globoso, pubescente, lobos do cálice persistentes e não reflexos.

Material selecionado: BRASIL, MARANHÃO, São José de Ribamar, praia de Panaquatira, 25.I.2015, P.G. Lima 545 (MAR). São Luís, praia da Guia, 26.X.2016, G.A. Amorim 302 (MAR); 04.II.2017, G.S. Amorim 304 (MAR). Raposa, Ilha de Curupu, 02.XI.2015, M.A. Machado 115 (MAR).

Psidium guajava possui distribuição no México, Caribe, Brasil, Bolívia, Chile e Argentina (GBIF 2017). No Brasil se distribui em quase todo território, em área de Floresta Amazônica, Caatinga, Cerrado e Mata Atlântica (BFG 2015). No litoral da Ilha do Maranhão foi encontrada nas dunas da praia da Guia e nas restingas da praia de Panaquatira e Ilha de Curupu, com floração registrada em agosto e frutificação em outubro, novembro e janeiro.

Essa espécie não é nativa da flora brasileira (BFG 2015). $P$. guajava apresenta nervura central e secundária bem marcada em ambas as faces, lobos do cálice rompendo-se irregularmente. $P$. guajava assemelha-se a $P$. guineense Sw. porém a primeira apresenta indumento esbranquiçado, margem plana, ovário 5-plurilocular enquanto a segunda apresenta indumento ferrugíneo, margem revoluta e ovário 4-5-locular. Algumas outras características podem auxiliar na separação dessas espécies, como número e espaçamento das nervuras secundárias e tamanho dos pedicelos, porém, por vezes se sobrepõem tornando difícil a separação apenas por esses caracteres (Tuler et al. 2017).

\section{AGRADECIMENTOS}

Os autores agradecem ao Conselho Nacional de Desenvolvimento Científico e Tecnológico (CNPq) pela concessão de bolsa à primeira autora; à Fundação de Amparo à Pesquisa e ao Desenvolvimento Científico e 
Tecnológico do Maranhão (FAPEMA) pela concessão da bolsa de produtividade ao último autor e financiamento dos projetos que possibilitaram o suporte financeiro. Ao curador e técnicos do Herbário do Maranhão (Herbário MAR). E ao Laboratório de Estudos Botânicos pelos recursos humanos com as parcerias das coletas. Ao $\operatorname{prof}^{\mathrm{o}} \mathrm{Dr}^{\mathrm{o}}$ Marcos Sobral pela confirmação das espécies e esclarecimentos de algumas dúvidas durante a construção do trabalho. A Kauê Nicolas Dias pelas ilustrações das espécies.

\section{REFERÊNCIAS}

Absy, M.L., Bezerra, E.B. \& Kerr, W.E. 1980. Plantas nectaríferas utilizadas por duas espécies de Melipona da Amazônia. Acta Amazonica 10(2):271-282.

Almeida Jr., E.B., Santos-Filho, F.S., Araujo, E.L. \& Zickel, C.S. 2011. Structural characterization of the woody plants in restinga of Brazil. Journal of Ecology and the Natural Environment 3(3): 95-103.

Almeida Jr., E.B., Silva A.N.F., Lima, G.P., Amorim, I.F.F., Serra, F.C.V., Correia, B.E.F., Machado, M.A., Almeida, R.A.G., Castro, A.R.R., Figuereiro, N., Silva, R.M. \& Santos-Filho, F.S. 2017. Checklist of the flora of the restingas of Maranhão State, northeast, Brazil. Indian journal of applied research 7(5): 603-612.

Almeida Jr., E.B. \& Zickel, C.S. 2012. Análise fitossociológica do estrato arbustivo-arbóreo de uma floresta de restinga no Rio Grande do Norte. Revista Brasileira Científica Agrária 7(2): 286-291.

Alvares, C.A., Stape, J.L., Sentelhas, P.C., Moraes Gonçalves, J.L. \& Sparovek, G. 2013. Köppen's climate classification map for Brazil. Zeitschrift 22(6):711-728.

Amaral, D.D.D., Prost, M.T., Bastos, M.D.N.D.C., Costa Neto, S.V. \& Santos, J.U.M.D. 2008. Restingas do litoral amazônico, estados do Pará e Amapá, Brasil. Boletim do Museu Paraense Emílio Goeldi Ciências Naturais 3(1): 35-67.

Amorim, G.S., Amorim, I.F.F. \& Almeida Jr., E.B. 2016. Flora de uma área de dunas antropizadas na praia de Araçagi, Maranhão. Revista Biociências 22(2): 18-29.

Arantes, A.A. \& Monteiro, R. 2002. A família Myrtaceae na Estação Ecológica do Panga, Uberlândia, Minas Gerais, Brasil. Lundiana 3(2): 111-127

Araujo, A.C.M, Silva, A.N.F, Almeida Jr., E.B. 2016. Caracterização estrutural e status de conservação do estrato herbáceo de dunas da Praia de São Marcos, Maranhão, Brasil. Acta Amazonica 46(3): 247-258.

Assis, A.M., Thomaz, L.D. \& Pereira, O.J. 2004. Florística de um trecho de floresta de restinga no município de Guarapari, Espírito Santo, Brasil. Acta Botanica Brasilica 18(1): 191-201.

Assumpção, J. \& Nascimento, M.T. 2000. Estrutura e composição florística de quatro formações vegetais de restinga do complexo lagunar Grussaí/Iquipari, São João da Barra, RJ, Brasil. Acta Botanica Brasilica 14(3): 301-315.

Brasil Flora Grupo - BFG. 2015. Growing knowledge: an overview of Seed Plant diversity in Brazil. Rodriguésia 66(4): 1085-1113.

Bünger, M.D.O., Scalon, V.R., Sobral, M. \& Stehmann, J.R. 2012. Myrtaceae in the Parque Estadual do Itacolomi, Minas Gerais, Brasil. Rodriguésia 63(4): 857-881.

Cabral-Freire, M.C. \& Monteiro, R. 1993. Florística das praias da Ilha de São Luís, Estado do Maranhão (Brasil): Diversidade de espécies e suas ocorrências no litoral brasileiro. Acta Amazonica 23(2-3): 125-140.

Cruz, F., Turchetto-Zolet, A.C., Veto, N., Mondin, C.A., Sobral, M., Almerão, M. \& Margis, R. 2013. Phylogenetic analysis of the genus Hexachlamys (Myrtaceae) based on plastid and nuclear DNA sequences and their taxonomic implications. Botanical Journal of the Linnean Society 172: 532-543.

De Lannoy, L.C., Goldenberg, R., Lima, D.F., 2019. Taxonomic rearrangements and typifications in Myrcia sect. Tomentosae (Myrteae, Myrtaceae). Phytotaxa 404(3): 111-120.
Flora do Brasil 2020 em construção. Jardim Botânico do Rio de Janeiro. Disponível em: http://floradobrasil.jbrj.gov.br/reflora/floradobrasil/ FB36968. Acessado em 25.09.2018.

Falcão, M.D.A., Ferreira, S.A., Clement, C.R., Barros, M.J.B., Brito, J. \& Santos, T.C. 1988. Aspectos fenológicos e ecológicos do" AraçaBoi"(Eugenia stipitata McVaugh) na Amazônia Central. I. Plantas juvenis. Acta Amazonica 18(3-4): 27-38.

Forzza R.C., Baumgratz, J.F.A., Bicudo, C.E.M., Carvalho Jr., A.A., Costa, A., Costa, D. P., Hopkins, M., Leitman P. M., Lohmann, L. G., Maia, L.C., Martinelli, G., Menezes, M., Morim, M.P., Coelho, M.A.N, Peixoto, A.L., Pirani, J. R., Prado, J., Queiroz, L.P., Souza, V.C., Stehmann, J. R., Sylvestre, L.S., Walter, B.M.T., Zappi, D. 2012. Catálogo de Plantas e Fungos do Brasil. Jardim Botânico do Rio de Janeiro, Rio de janeiro. $1150 \mathrm{p}$.

Galvão, F., Roderjan, C.V., Kuniyoshi, Y.S. \& Ziller, S.R., 2002. Composição florística e fitossociologia de caxetais do litoral do estado do Paraná-Brasil. Floresta 32(1): 17-39.

Global Biodiversity Information Facility- GBIF. Disponível em: https:// www.gbif.org/species/search?q=Myrtaceae. Acessado em 25.09.2018.

Giaretta, A.; Peixoto, A.L. 2015. Myrtaceae da restinga no norte do Espírito Santo, Brasil. Boletim do Museu de Biologia Mello Leitão 37(1): 45-126.

Govaerts, R., Sobral, M., Ashton, P., Barrie, F., Holst, B. K., Landrum, L. L., Matsumoto, K., Mazine, F. F., Nic Lughadha E., Proença, C. Soares-Silva, L. H., Wilson P. W., Lucas, E. 2008. World Checklist of Myrtaceae. Kew Publishing, Royal Botanic Gardens, Kew. 470 p.

Guedes, D., Barbosa, L.M. \& Martins, S.E. 2006. Composição florística e estrutura fitossociológica de dois fragmentos de floresta de restinga no Município de Bertioga, SP, Brasil. Acta Botanica Brasilica 20(2): 299-311.

Harris, J. G., Harris, M. W. 1994. Plant Identification Terminology an Illustrated Glossary. Spring Lake Publishing, Spring Lake, Utah.

Instituto Nacional de Meteorologia - INMET. Disponível em http://www. inmet.gov.br/portal/. Acessado em 25.09. 2018.

Judd, W.S., Campbell, C.S., Kellogg, E.A., Stevens, P.F. \& Donoghue, M.J. 2009. Sistemática Vegetal: um enfoque filogenético. Artmed, Porto Alegre. 612p.

Landim, M.F. \& Landrum, L.R. 2002. The genus Campomanesia (Myrtaceae) in Atlantic rainforest fragments in Sergipe, northeast region of Brazil. SIDA, Contributions to Botany 20(1): 205-214.

Landrum, L.R. 1986. Campomanesia, Pimenta, Blepharocalyx, Legrandia, Acca, Myrrhinium and Luma (Myrtaceae). Flora Neotropica 45:1-178.

Landrum, L.R. \& Kawasaki, M.L. 1997. The genera of Myrtaceae in Brazil: an illustrated synoptic treatment and identification keys. Brittonia 49(4): 508-536.

Landrum, L.R. 2010. A Revision of Calycolpus (Myrtaceae). Systematic Botany 35(2), 368-389.

Lourenço, A.R.L. \& Barbosa, M.R.V. 2012. Myrtaceae em restingas no limite norte de distribuição da Mata Atlântica, Brasil. Rodriguésia 63(2): 373-393.

Luber, J., Oliveira, M.I.U., Ferreira, M.F.S. \& Carrijo, T.T. 2017. Flora of Espírito Santo: Campomanesia (Myrtaceae). Rodriguésia 68(5): $1767-1790$.

Lucas, E.J. \& Bünger, M.O. 2015. Myrtaceae in the Atlantic forest: their role as a 'model'group. Biodiversity and Conservation 24(9): 2165-2180.

Lucas, E.J., Harris, S.A, Mazine, F.F., Belsham, S.R., Nic Lughadha E.M., Telford, A., Gasson, P.E. \& Chase, M.W. 2007. Suprageneric phylogenetics of Myrteae, the generically richest tribe in Myrtaceae (Myrtales). Taxon 56(4): 1105-1128.

Lucas, E.J., Holst, B., Sobral, M., Mazine, F.F., Nic Lughadha, E.M., Proença, E.C.B., Costa, I.R., Vasconcelos, T.N.C. 2019. A new subtribal classification of tribe Myrteae (Myrtaceae). Systematic Botany 44(3): 560-569.

Machado, M.A. \& Almeida Jr, E.B., 2019. Spatial Structure, Diversity, and Edaphic Factors of an Area of Amazonian Coast Vegetation in Brazil1. The Journal of the Torrey Botanical Society 146(1): 58-68.

Martins, S.E., Rossi, L., Sampaio, P.D.S.P. \& Magenta, M.A.G. 2008. Caracterização florística de comunidades vegetais de restinga em Bertioga, SP, Brasil. Acta Botanica Brasilica 22(1): 249-274. 
Matias, L.Q. \& Nunes, E.P. 2001. Levantamento florístico d o florístico d o florístico da área de proteção ambiental de Jericoacoara, Ceará. Acta Botanica Brasilica 15(1): 35-43.

Mazine, F.F. \& Faria, J.E.Q., 2013. A new species of Eugenia (Myrtaceae) from South America. Phytotaxa 151(1): 53-57.

Mazine, F.F., Bünger, M.O., Faria, J.E.Q., Lucas, E. \& Souza, V.C. 2016. Sections in Eugenia (Myrteae, Myrtaceae): nomenclatural notes and a key. Phytotaxa 289(3): 225-236.

Menezes, C.M., Santana, F.D., Silva, V.S., Silva, V.I. \& Araújo, D.S., 2012. Florística e fitossociologia em um trecho de restinga no Litoral Norte do Estado da Bahia. Biotemas, 25(1): 31-38.

Morais, P.O. \& Lombardi, J.A. 2006. A família Myrtaceae na reserva particular do patrimônio natural da Serra do Caraça, Catas Altas, Minas Gerais, Brasil. Lundiana 7 (1): 3-32.

Muniz, F.H., Cesar, O. \& Monteiro, R. 1994. Aspectos florísticos quantitativos e comparativos da vegetação arbórea da Reserva Florestal do Sacavém, São Luís, Maranhão (Brasil). Acta Amazonica 24(3/4): 189-218.

Oliveira, E.V.S., Lima, J. F., Silva, T.C. \& Landim, M.F. 2014. Checklist of the flora of the Restingas of Sergipe State, Northeast Brazil. Check List 10(3): 529-549.

Paraluppi, N.D., Clement, C.R. \& Falcão, M.A. 2002. Fenologia e produtividade do jambo (Syzygium malaccensis) na Amazônia Central. Acta Amazonica 32(1): 3-8

Peixoto, A.L. \& Maia, L.C. 2013. Manual de Procedimentos para Herbários. Editora Universitária UFPE, Recife, PE.

Pinheiro, J.M. 2017. Distribuição espaço-temporal da pluviosidade na Ilha do Maranhão no ano de 2016. InterEspaço: Revista de Geografia e Interdisciplinaridade, 3(8): 126-141.

Queiroz, E.P., Cardoso, D.B.O.S. \& Ferreira, M.H.S. 2012. Composição florística da vegetação de restinga da APA Rio Capivara, Litoral Norte da Bahia, Brasil. Sitientibus 12(1): 119-141.

Rosário, A.S., Baumgratz, J.F.A. \& Secco, R.S. 2014a. Contribution to the taxonomy of Marlierea (Myrciinae; Myrtaceae) in Brazil. Rodriguésia 65(1): 245-250.

Rosário, A.S., Baumgratz, J.F.A. \& Secco, R.S. 2014b. Taxonomic notes in Calyptranthes (Myrciinae; Myrtaceae) in the Brazilian Amazon. Phytotaxa 186(3): 158-165.

Rosário, A.S., Baumgratz J.F.A \& Secco, R.S. 2017. Taxonomic studies of Myrcia (Myrciinae, Myrtaceae) in Brazil: morphological novelties, circumscriptions, and new records for the Amazon. Iheringia. Serie Botânica 72(2): 165-172.

Rosário, A.S. \& Secco, R.D.S. 2006. Sinopse of the species of Marlierea Cambess. (Myrtaceae) in Amazonian Brazil. Acta Amazonica 36(1): pp.37-51.

Rosário, A.S. \& Secco, R.S. 2013. Contribuição à taxonomia das Myrtaceae da Floresta Nacional de Caxiuanã. In Caxiuanã: paraíso ainda preservado IV ed. (P.L.B. Lisboa, ed.). Museu Paraense Emílio Goeldi, p. 219-230.

Rosário, A.S., Secco, R.S.; Amaral, D.D., Santos, J.U.M. \& Bastos, M.N.C. 2005. Flórula fanerogâmica das restingas do estado do Pará. Ilhas de Algodoal e Maiandeua - 2. Myrtaceae A. L. de Jussieu. Boletim do Museu Paraense Emílio Goeldi, Série Ciências Naturais 1(3): 31-48.

Rosário, A.S., Secco, R.S. \& Silva, J.B.F. 2004. Notas sobre Ugni Turcz. (Myrtaceae) na Amazônia Brasileira. Acta Amazonica 34(1): 139-141.

Sacramento, A.C.S.; Zickel, C.S. \& Almeida Jr., E.B. 2007. Aspectos florísticos da vegetação de restinga no litoral de Pernambuco. Revista Árvore 31(6): 1121-1130.

Santos, M.F. \& Sano, P.T. 2012. Flora of the Serra do Ouro Branco, Minas Gerais: Myrtaceae. Rodriguésia 63(4): 1065-1083.
Scherer, A.; Maraschin-Silva, F. \& Baptista, L.R.M. 2005. Florística e estrutura do componente arbóreo de matas de Restinga arenosa no Parque Estadual de Itapuã, RS, Brasil. Acta Botanica Brasilica 19(4): 717-726.

Serra, F.C.V.; Lima, P.B. \& Almeida Jr, E.B. 2016. Species richness in restinga vegetation on the eastern Maranhão State, Northeastern Brazil. Acta Amazonica 46(3): 271-280.

Silva, A.N.F.; Araujo, A.C.M. \& Almeida Jr., E.B. 2016. Flora Fanerogâmica das Dunas da Praia de São Marcos, São Luís, Maranhão. In Biodiversidade do Meio Norte do Brasil, conhecimentos ecológicos e aplicações (E. B. Almeida Jr.; F. S. Santos-Filho, org.). Curitiba: Editora CRV, p. 11.

Silva, F.K.S., Rosário, A.S., Secco, R.S, \& Zoghbi, M.D.G.B. 2015. Levantamento das espécies conhecidas como pedra-ume-caá (Myrtaceae), com ênfase nas comercializadas na cidade de Belém, Pará, Brasil. Biota Amazonia 5(1): 7-15.

Souza, M.A.D.; Kawasaki, M.L.; Holst, B.K. 1999. Myrtaceae. In: RIBEIRO, J. E. L. S. et al. Flora da Reserva Ducke, Guia de identificação das plantas vasculares de uma floresta de terra-firme na Amazônia Central (Ribeiro, J.L.S. Hopkins, M.J.G., Vicentini, A., Sothers, C.A., Costa, M.A.S., Brito, J.M.D., Souza, M.A.D., Martins, L.H.P., Lohmann, L.G., Assuncao, P.A.C.L., Pereira, E.C., Silva, C.F., Mesquita, M.R. \& Procopio, L.C. Org.) INPA, Manaus, p. 417-436.

Souza, M.A.D., Scudeller, V.V. \& Mendonca, M.S. 2015. Three new species of Eugenia (Myrtaceae) from Brazilian Amazonia. Phytotaxa 212(1): 87-94.

Souza, V.C. \& Lorenzi, H. 2005. Botânica sistemática: guia ilustrado para identificação das famílias de Angiospermas da flora brasileira, baseado em APG II. Instituto Plantarum. 640 p.

Stadnik, A.; Oliveira, M.I.U. \& Roque, N. 2016. Levantamento florístico de Myrtaceae no município de Jacobina, Chapada Diamantina, Estado da Bahia, Brasil. Hoehnea 43(1): 87-97.

Suguino, E., Glória, B.A., Araújo, P.S.R. \& Simão, S. 2003. Propagação vegetativa de camu-camu por meio de enxertia intergenérica na família Myrtaceae. Pesquisa Agropecuária Brasileira 38(12): 14771482.

Teixeira, A.S., Chaves, L.D.S. \& Yuyama, K. 2004. Esterases no exame da estrutura populacional de Camu-camu (Myrciaria dubia (Kunth) McVaugh-Myrtaceae). Acta Amazonica 34(1): 89-96.

Thiers, B. [continuously updated]. Index Herbariorum: A global directory of public herbaria and associated staff. New York Botanical Garden's Virtual Herbarium. Disponível em: http://sweetgum.nybg.org/science/ ih/. Acessado em 25.09.2018.

Trindade, J.R., Rosário, A.S. \& Santos, J.U.M. 2018. Flora das cangas da Serra dos Carajás, Pará, Brasil: Myrtaceae. Rodriguésia 69(3): 1259-1277.

Tropicos.org. Missouri Botanical Garden. Disponível em: http://www. tropicos.org/Name/22100751. Acessado em 25.09.2018.

Tuler, A.C., Carrijo, T.T., Ferreria, M.F. and Peixoto, A.L. 2017. Flora of Espírito Santo: Psidium (Myrtaceae). Rodriguésia 68(5): 1791-1805.

Viana, B.F.; Silva, F.O. \& Kleiner, A.M.P. 2006. A flora apícola de uma área restrita de dunas litorâneas, Abaeté, Salvador, Bahia. Revista Brasileira de Botânica 9 (1): 13-25.

World Checklist of Selected Plant Families - WCSP 2017. Disponível em: <apps.kew.org/wcsp/>. Acessado em 25.09.2018.

Wilson, P.G., O’Brien, M.M., Gadek, P.A. \& Quinn, C.J. 2001. Myrtaceae revisited: a reassessment of infrafamilial groups. American Journal of Botany 88(11): 2013-2025.

Wilson, P.G., O’Brien, M.M., Heslewood, M.M \& Quinn, C.J. 2005. Relationships within Myrtaceae sensu lato based on a matK phylogeny. Plant Systematics and Evolution 251(1): 3-19. 